\title{
ハイドロキシアパタイト製スクリュー $\left(\mathrm{K}-\mathrm{CHAS}^{\mathrm{TM}}\right)$ による頚椎前力固定術
}

\author{
栗林 厚介，松田 昌之*
}

\author{
Anterior Cervical Fusion with the Kosuke-Cervical Hydroxyapatite Screw (K-CHAS ${ }^{\mathrm{TM}}$ ) \\ by \\ Kosuke Kuribayashi, Masayuki Matsuda* \\ from \\ Department of Neurosurgery, Tanabe Central Hospital \\ Department of Neurosurgery, Shiga University of Medical Science*
}

Recently, the use of hydroxyapatite as a substitute for an iliac bone graft in anterior cervical fusion has been reported, but is associated with some problems, such as a slip out of the hydroxyapatite plugs or the development of a radiolucent zone around the implant on postoperative X-rays. While porous hydroxyapatite promotes bony ingrowth, a significant number of implant collapses have been reported. To avoid these complications, anterior titanium plates or cages are used. Patients treated with an anterior plate, however, run the risk of not only hardware complications but also a decreased fusion rate for single-level fusion. On the other hand, the use of the titanium cages occasionally leads to vertebral body collapse. Moreover, cages cause an artifact on magnetic resonance T2-weighted axial imaging. We have developed a new implant in order to avoid all those drawbacks and complications. The device, which we call the K-CHAS, is made of dense hydroxyapatite and $\beta$-tricalcium phosphate ( $\beta$-TCP) composite, is $11 \mathrm{~mm}$ in length, $8 \mathrm{~mm}$ in anterior diameter and $7 \mathrm{~mm}$ in posterior diameter, and is threaded. The K-CHAS can withstand a compression force of $501 \mathrm{~kg} / \mathrm{cm}^{2} . \beta-\mathrm{TCP}$ actively promotes osteogenesis and can be eventually replaced by bone. The Smith-Robinson's procedure is indicated, in which two implants are screwed into the intervertebral space in parallel. There is no need to harvest or collect bone. We have used this implant at 42 levels in 37 patients, with mean age of 55.4 years. Patients were placed in a hard cervical collar for 1 to 2 weeks after operation. They were allowed to walk on the second postoperative day. There were no intraoperative complications. Radiological follow-up showed neither instability nor any radiolucent zones. The K-CHAS provides immediate, solid stability of the cervical spine and brings about early fusion in the anterior cervical spine surgery.

Key word: cervical anterior interbody fusion, K-CHAS, hydroxyapatite, $\beta$-TCP, vertebral spacer

Spinal Surgery $16(2): 119 \sim 126,2002$

\section{はじめに}

頝椎前方固定はSmith, Robinson, Clowardら [6, 39にによって始められ，今や頚椎変性疾患に対する治療 として確立された手技となった，当初から，現在に至る まで，その補填材料として自家腸骨が多く用いられてき たが，その移植骨自身の問題や採取部の合併症の回避， 手術時間の短縮のためにハイドロキシアパタイトが人工
材料として使用されるようになったしいし，時に自家 骨と同様に圧潰が起こったり，瘉合不全，脱転が起こる こともある．自家骨，人工骨を問わず，それらを防ぐた めに，金属製プレートの併用も行われるようになり，金 属製プレートも改良がなされ，その破損の危険は極めて 少なくなったものの，その併用は骨癒合の妨げになった り，プレートの挿入や脱転などの際に周辺組織を損傷さ 


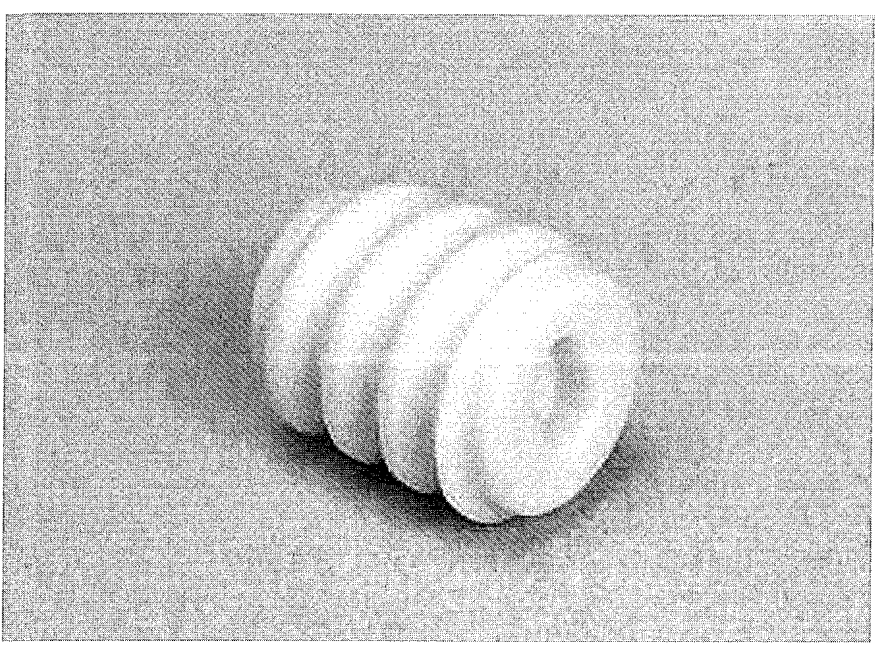

Fig. 1 : Whole view of the K-CHAS.

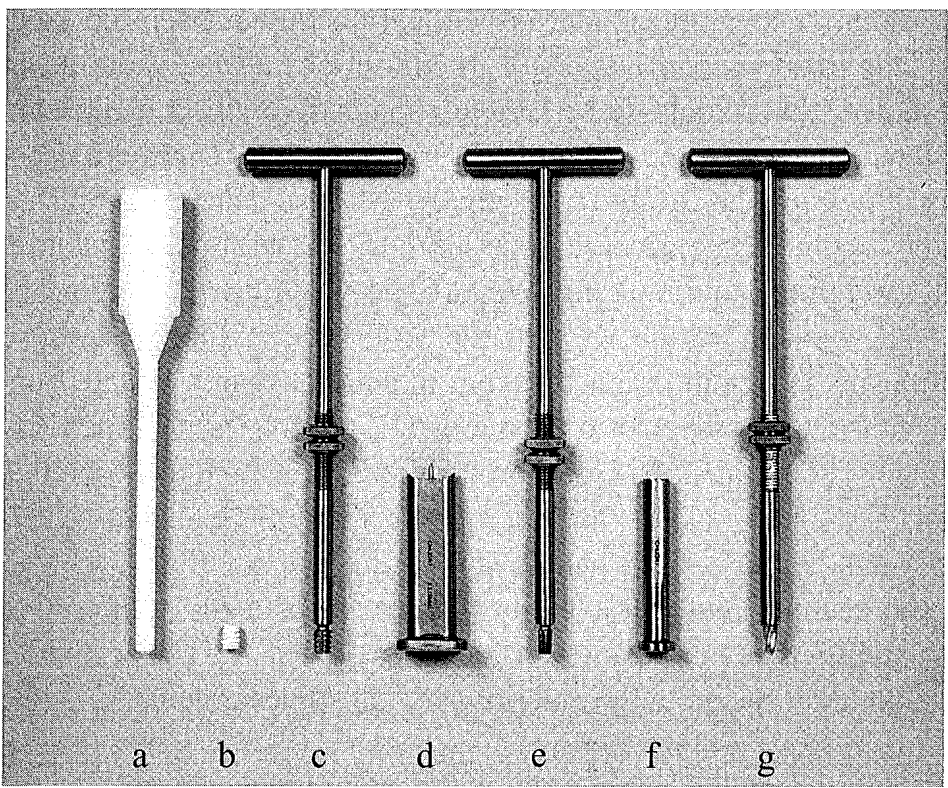

Fig. 3 : Photograph of instruments used for the K-CHAS implantation.

a: driver. b: K-CHAS. c: tap. d: double sheath.

e: reamer. f: single sheath. g: drill

せる危険性は残存する，また，骨瘉合を高めるために八 イドロキシアパタイトの緻密体の代わりに多孔体を用い ると, 強度が不足し，その破損の危険が高まる。これら を回避したり，手術手技のさらなる簡略化，また入院必 要期間の短縮のために, 頚椎部にも腰椎部に使用されて きたチタン製のケージの有用性が報告され，使用される ようになった。しかし，時に椎体破壞などの合併症が起 こり得る，そこで，今回ハイドロキシアパタイト製スク リューのインプラントであるK-CHAS（製造：日本特殊
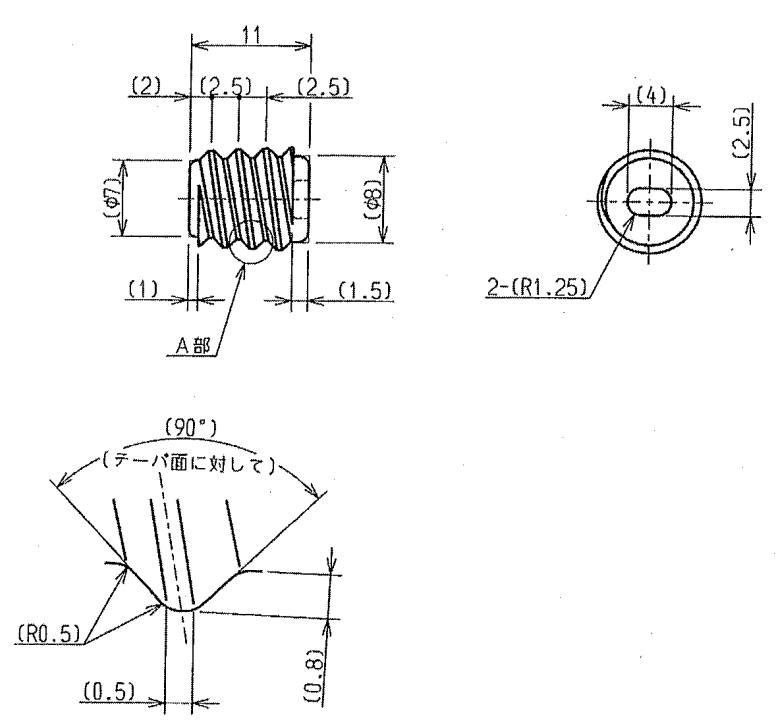

A 部詳細(10:1)

Fig.2 : Designs and dimensions of the K-CHAS.

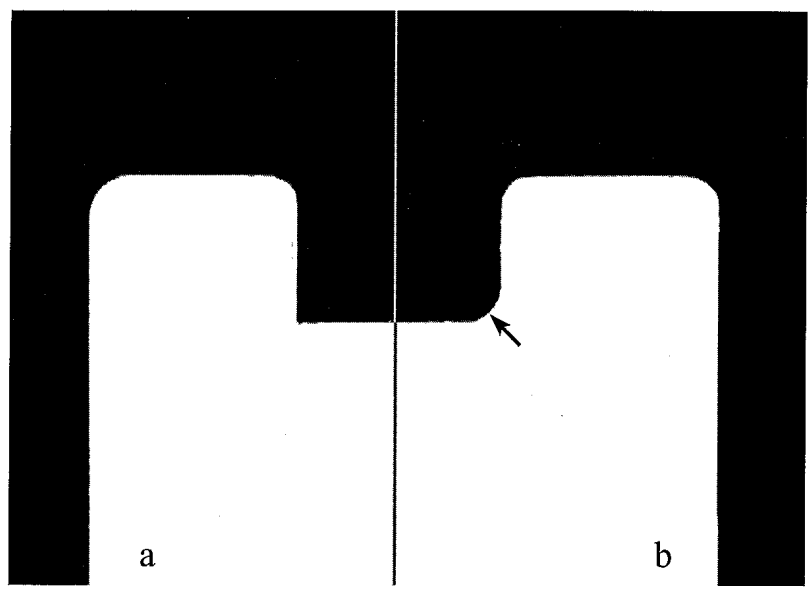

Fig. 4 : Sagittal section of the driver hole of the K-CHAS.

a. Prototype. b. Current type.

Current type is more resistant to the stress because of the arc (arrow).

陶業株式会社, 販売：小林製薬株式会社）を作成，臨床 応用し有用であったので報告する。

\section{対象および方法}

材質はハイドロキシアパタイトと $\beta$-リン酸三カルシ ウム（ $\beta$-TCP） がそれぞれ $80 \% ， 20 \%$ からな複合体の 緻密体で, K-CHASの圧縮強度は $501 \mathrm{~kg} / \mathrm{cm}^{2}$ である。形 
状は長さ $11 \mathrm{~mm}$, 腹側の直径が $8 \mathrm{~mm}$, 背側の直径が $7 \mathrm{~mm}$ のテーパーを持つ（Fig. 1,2）ことによって脊柱 管内への脱出を防ぐ、ネジ溝を持つことにより, チタン 製ケージのように，専用の周辺器械（Fig. 3 ）を用いて 㧖じ达み式に挿入することができる．また，ハイドロキ シアパタイトは剪断力に弱いため, ドライバー保持部分 に挿入時に当初, 亀裂を生じることがあったが, 底に丸 みを付けることによって，トルク強度が $2.36 \mathrm{kgf} \cdot \mathrm{cm}$ ら $4.84 \mathrm{kgf} \cdot \mathrm{cm}$ と改善し, 実用に耐えられるようになっ た (Fig. 4 ). 手術術式はSmith-Robinson法で行う. Casper vertebral spreaderを上下椎体に固定し，ごく軽 度distractionをかけて, 専用sheathを打ち込みdrilling を椎間に平行に 2 ケ所行う. その後, distractionを十分 に強めてから, 減压を行い, distractionを一旦弱め, 専 用reamerで整え, tapを設ける。その際にはK-CHASの 溝の谷が皮質骨に接し，山が髄質内に位置するように tapを設けるとsinkingを防ぎ，確実に骨癒合がもたらさ れる。そして，再度軽度のdistractionをつけ，K-CHAS を滑らせるように㨝じ达み，distractionを取り去ると， 強固に固定される，後療法は，1椎間固定の場合は硬性 カラーを 1 週間, 次いで軟性カラーを 3 週間, 2 椎間固 定の場合は硬性カラーを 2 週間，次いで軟性カラーを 6 週間装着させ，歩行は手術翌日に開始，機能撮影は 3 ケ 月後より行っている.

37例（男性 28 例，女性 9 例，平均年齢55.4（23-82） 歳）に使用した. 32 例が 1 椎間， 5 例が 2 椎間固定の計 42 椎間である. 平均追跡期間は 15 ケ月（1-30ケ月）で, 期間中66歳の男性が 3 ヶ月後に急性心筋梗塞で, 82歳の 男性が 1 年後に悪性新生物で死亡した．評価は日本整形 外科学会䅡髄症治療成績判定基準 (JOA score: 満点17 点）［26］で行った.

\section{結 果}

術前平均JOA score 12.4点が術後平均16.8点に改善し, 術中, 術後の合併症はみられなかった. 正確に㴗が設け られた場合には, 手術翌日のX線撮影でも, 周囲骨透梁 像は認めない。溝がやや大きすぎたと考えられる初期の 6 例に手術翌日のX線撮影で周囲骨透梁像が見られ, そ のうちの 4 例に手術後 1 ヶ月以内に, 片側のK-CHASに 1 ピッチ以内の腹側への移動が見られたが, それ以降の 移動は見られず安定している．また，片側のK-CHASの 中心が上位椎体のやや外側寄りに置かれた 1 例で, その K-CHASが外側に脱出し, 椎間腔内に残った方のK-
CHASが圧潰し，再手術を要した，それ以外のK-CHAS の圧潰は見られなかった．逆に椎体の破壊はもちろん， sinkingも見られなかった. 追跡期間が 1 年以上を経過 した 27 例のうち, 当初周囲骨透梁像の見られた 6 例も含 めた観察可能な 24 例全例で周囲骨透梁像は見られなかっ た. また, 手術後 1 ヶ月以内に腹側への移動が見られた 4 例も含めて, 1 年経過後も手術 1 ケ月後の位置と変化 がなく, 機能撮影でも固定部に動きを認めた症例はなか った。また，16例にanterior bridging boneを認めた。

\section{<症例 $>$}

65 歳男性. 数年前よりの右䅡部痛, 3 ケ月前よりの 両側前腕痛を呈し, CT myelography, MRIで骨棘によ る神経圧迫を認めた（Fig. 5 ). K-CHASを用いてC5-6椎 間に前方固定手術を行い，症状は完全に消失し，JOA scoreも14点から満点の17点に改善した. 生理的前弯が 保たれ，T2 強調MR axial画像でartifactの影響を受けず に，神経が十分に減圧されていることを評価することが できた（Fig. 6)。手術翌日より明らかな周囲骨透梁像 は見られず，その後の位置も安定し，12ヶ月までは骨の 変化を認めなかった. 術後18ヶ月でbridging boneがC 6 椎体に接するK-CHASの前面より頭側に伸長し，24ヶ月 で完成していた（Fig.7）.

\section{考 察}

頝椎前方固定には移植骨として腸骨から採取した自家 骨が使われてきたが，採骨にあたって，採骨部の痛みや 血腫, 感染, 外側大腿皮神経障害, 前腸骨棘破損の危険 がある $[2 ， 3 ， 4 ， 11 ， 33 ， 37,38]$ ことや，移植骨 の吸收, 骨折, 脱転, 骨瘉合不全などの危険がある $[2$, $4 ， 11 ， 33,34,38]$. 採取の際の合併症は工夫により 減少しえるが, 採取部の感覚变化などの合併症を皆無に することは困難である [3]．したがって，欧米では同 種移植骨が代わりに用いられることが多い.しかし，金 属製プレートを併用すれば優れた骨癒合をもたらすとの 報告もある [8] が, 一般に自家骨に比して骨癒合成績 が悪いことが報告 $[1,47]$ され，また感染の危険もあ る. 日本では，同種移植骨を使用できる施設が限られて いることもあり，セラミックなどの研究が進んだ。臨床 応用も織田らのバイオセラム [28] から始まり，ハイド ロキシアパタイトへと進化した．これらの進化発展の歴 史は小山によって詳しく記載されている [18]．このハ イドロキシアパタイトによる前方固定手術は自家骨に比 


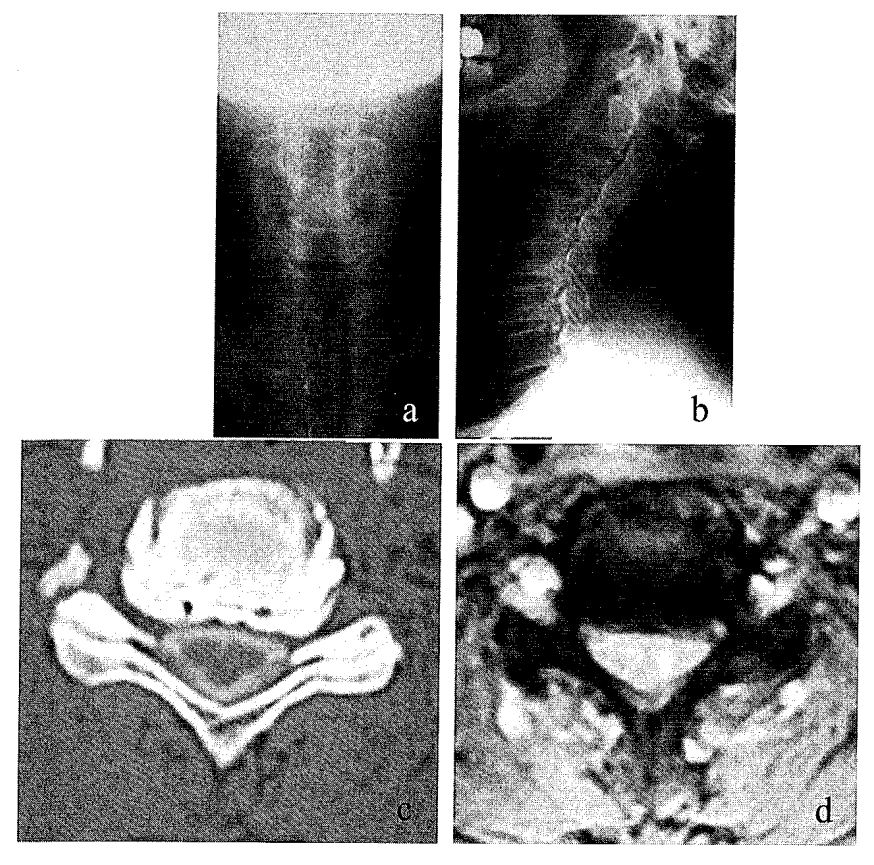

ベて勝るとも劣らない $[17,38]$ とされ，ハイドロキシ アパタイトが移植腸骨の代用補填材料として広く用いら れるようになった. しかし，ハイドロキシアパタイトで も，時に破壊や脱転することもある $[14 ， 38]$ 。また， ハイドロキシアパタイト周囲に明らかな骨透梁像が見ら れることもある [13]。これはX線上, 非金属製インプ ラントは金属製インプラントより周囲骨透梁像があるよ うに見えやすい［5］ということだけでなく，ハイドロ キシアパタイトは骨形成促進作用はあるものの，吸収さ れずに異物として残存し，自家骨化が進行しないため真 の骨癒合は起こらない $[30,36]$ ことが原因と考えられ る・したがって，気孔部での骨新生や骨侵入による骨 癒合を期待し，多孔体を用いることもある。しかし，気 孔率上昇とともに，著しい強度低下をきたし，スペーサ 一の破壊が高頻度で起こることになる $[14 ， 35 ， 42 ４ 66]$. そのため金属製プレートの併用が钊められている $[42$, 46]. 近年，プレート破損の危険はほとんどなくなり， 自家骨にプレートを併用する場合には，併用により経年 的な生理的前弯袈失を予防したり [16]，2椎間以上の 場合は骨癒合に役立つ $[7 ， 43]$ が，1椎間でも効果が ある $[8 ， 44]$ という意見がある一方，効果に疑問があ る [7] という意見が対立している。

これらの久点の改善とさらなる手術手技の簡略化のた めに，近年腰椎変性疾患に有用である $[20 ， 21 ， 22 ， 32]$ チタン製ケージが澒椎部にも使用され有用であると報告 されている $[9,12,19,23]$. 時に, 腰椎部でも sinkingや椎体破壊による合併症の報告もある $[10,25]$
Fig. 5 : Preoperative myelographies, CT myelography and MR imaging.

a: Anteroposterior myelography showing decreased filling of bilateral $\mathrm{C} 6$ roots.

b: Lateral myelography showing compression of the dural sac at C4-5. C5-6 and C6-7 levels.

CT myelography(c) and T2 weighted axial image (d) showing compression of the nerve roots at the bilateral intervertebral foramina at C5-6.

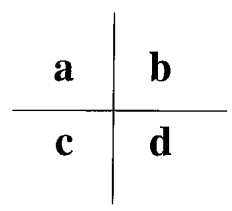

が，頚椎部でもケージの変位 [9] やsinking，椎体破 壊が起こること $[12 ， 23]$ や，MRI画像に障害がある [23]ことが報告されている.さらに，ケージ使用の際 にはケージ内に骨が存在することが骨瘾合判定の一つに 用いられるが, 頚椎部ケージは腰椎部ケージより小さい ため評価が困難である $[5]$ 。また，チタンは生物学的 に安全と言われているが，骨癒合がもたらされない場合， 電影的には細胞内にチタンが取り込まれることが報告さ れている [45]. チタン製ケージを頝椎部に使用すると， 腰椎部より sinkingや椎体破壊の危険が高い理由として, 以下のことが推測される．湿潤椎体の破壊荷重は, 頚椎 では平均 $315 \mathrm{~kg}$ に対し, 腰椎では $505 \mathrm{~kg}$, と頚椎椎体は 腰椎椎体の $3 / 5$ の過重にしか柎えられない. 加齢によ って頝椎, 腰椎ともに低下するが, 20,30歳代の腰椎椎 体破壊荷重730kgに対して，60，70歳代の頚椎椎体破壊 荷重は190kgでしかない [40].したがって, 頚椎部イ ンプラントに腰椎部インプラントと同じ材質を用いるこ とは, 椎体の破壊の危険が常に併存し, 特に高齢者に, その危険が高い。

一方, K-CHASはハイドロキシアパタイトと $\beta$-TCP の複合体からなる。 $\beta$-TCPはハイドロキシアパタイト と異なり，骨形成を促進させるだけでなく，自身が融 解・吸収され骨に置き換わる $[30 ， 31 ， 36]$ が，強度は 著しく弱い [15]. しかし，ハイドロキシアパタイト・ $\beta$-TCP複合体は強度も強く $[15]$, この複合体からなる 緻密体K-CHASの圧縮強度は $501 \mathrm{~kg} / \mathrm{cm} 2$ であり, ハイド ロキシアパタイトの緻密体に比べても, 遜色はなく, こ 

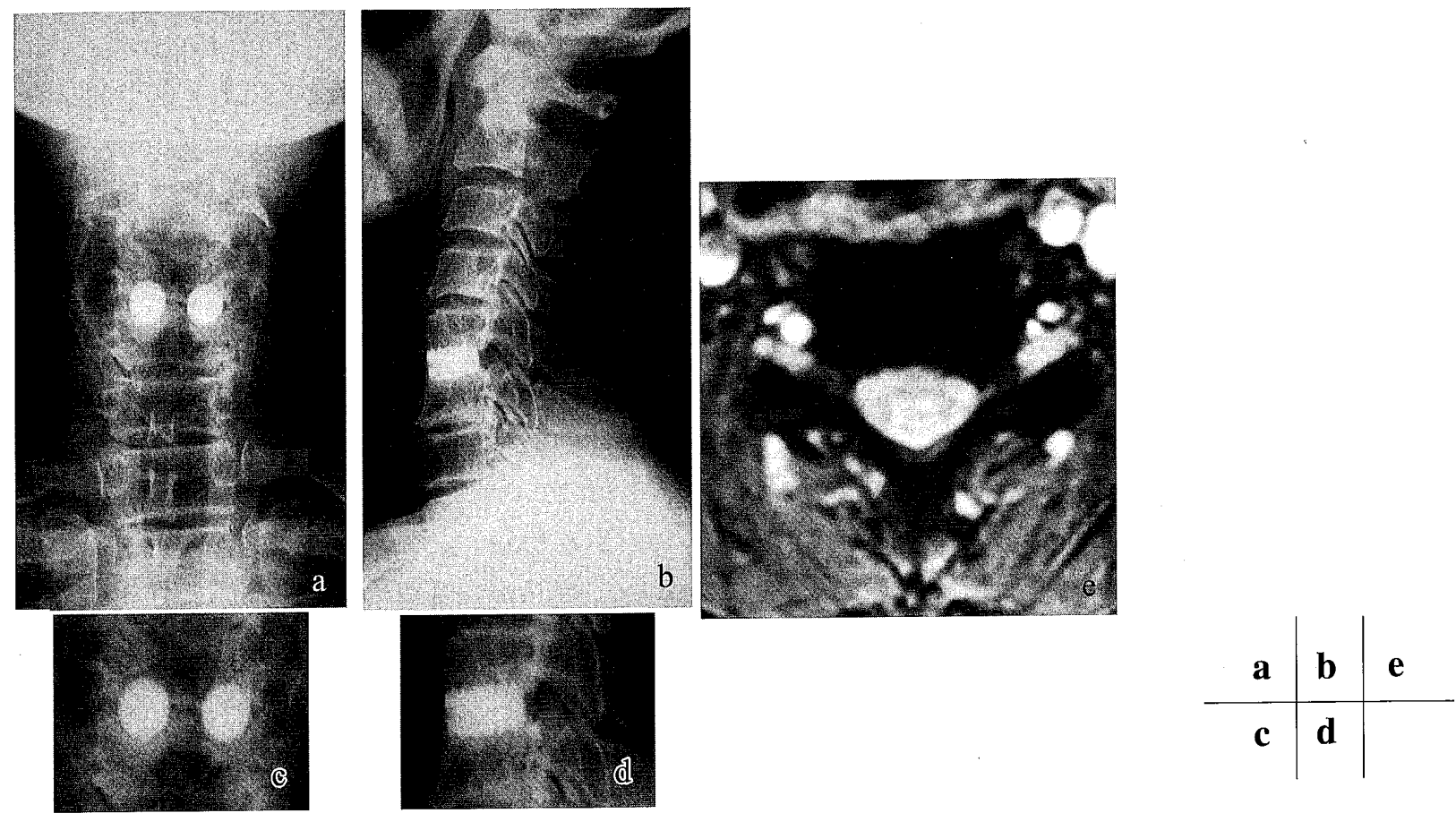

Fig. 6 : Postoperative roentgenograms and MR imaging.

a: Anteroposterior roentgenogram showing K-CHASs inserted bilaterally into the intervertebral space at C5-6.

b: Lateral roentgenogram showing restoration of physiological lordosis.

$\mathrm{c}, \mathrm{d}$ : Enlarged roentgenograms showing no remarkable radiolucent zone around the K-CHAS.

e: Postoperative T2-weighted axial MR image showing complete decompression of the cord and the nerve roots.

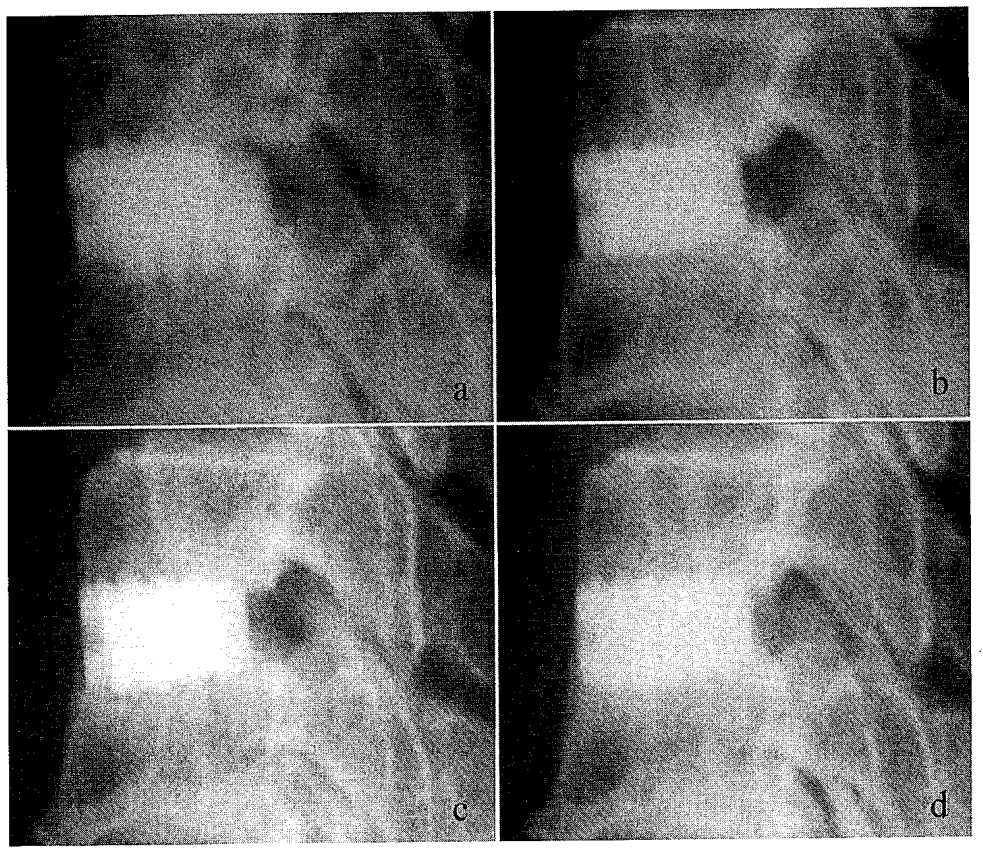

Fig.7 : Follow-up on postoperative roentgenograms. a: Postoperative day 2. b: One year after surgery. c: Eighteen months after surgery. d: Two years after surgery.

There was no radiolucent zone around the K-CHAS after surgery (a). There were no noticeable changes until one year after surgery (b). After 18 months, bridging bone began to grow(c). After 2 years, the $\mathrm{K}-\mathrm{CHAS}$ was surrounded by the bone (d).

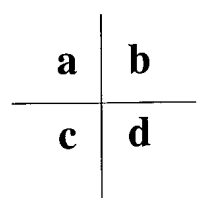

の価は澒椎脊椎骨の強度平均 $315 \mathrm{~kg}$ を上回り K-CHAS自 身が圧潰する危険性は極めて少ない。また，骨瘉合にお いても $\beta$-TCPを含有するためにハイドロキシアパタイ トより優れている [15]. 西山, 高戸らはハイドロキシ アパタイト・ $\beta$-TCP複合体は新生骨と直接結合する
$[27 ， 41]$ とし，松前は複合体と骨との接合部は鋸歯状 になり新生骨が複合体に入り込む $[24]$ と述べている. また，腰椎後側方固定術に切除自家骨と複合体を混合し て用いた小熊らは，骨癒合率は $93.3 \%$ と自家腸骨移植と 同等の優れた成績であったと報告している [29]. 
以上より, 頚椎前方固定用のインプラントである $\mathrm{K}-$ CHASには以下の点で優れると考える.

1 ）人体毒性のないハイドロキシアパタイト・ $\beta-\mathrm{TCP}$ 複合体製で， $\beta$-TCPに骨誘導能があるため, 真の骨癒 合が期待できる.

2）溝のおかげで骨との接地面積が増え, さらに骨痣合 性が高まる。

3）スクリューの形状のため, 初期固定力にも優れ, 金 属製プレートの併用や長期間の外固定が不要である.

4）腹側が大きいtaperを持つことにより，生理的前弯 の回復ができ，かつ泰柱管内への脱出がない.

5）材質的に適度な硬度を持ち，K-CHAS自身の圧潰や 椎体のsinkingや破填の危険性が極めて少ない。

6) 移植骨採取が不要である.

7 ）多くの場合, bridging boneが形成され骨瘉合判定 が容易である。

8）金属を用いないことより metal debrisの危険がなく, またMRI画像に影響を与えない。

K-CHASのサイズの搪充と正確なtapを刻める周辺器 械のさらなる改良によって，椎体の大きさに適したKCHASをより正確に挿入できるようにすることが今後の 課題である.

いかなる脊椎固定術であろうと, 確実な骨癒合が重要 である．生体人工材料の理想は，人体に無害で，適度な 強度を持ち, 初期固定力があり, 自家骨に置き換わるこ とである。これらの人工材料が開発されるまで，KCHASは䅡椎前方固定手術において有用なインプラント の一つである.

\section{謝 辞}

周辺器械の製作・改良に尽力いただいた中外製薬株式 会社＼cjkstart奥田浩氏に感謝致します。

\section{文 献}

1. An HA, Simpson JM, Glover JM, Stephany J: Comparison between allograft plus demineralized bone matrix versus autograft in anterior cervical fusion. Spine 20: 2211-2216, 1995

2. Aronson N, Filtzer DL, Bagan M: Anterior cervical fusion by the Smith-Robinson approach. J Neurosurg 29: 397-404, 1968

3. Banwart JC, Asher MA, Hassanein RS: Iliac crest bone graft harvest donor site morbidity; a statistical evaluation. 20: 1055-1060, 1995

4. Bohlman HH, Emery SE, Goodfellow DB, Jones PK: Robinson anterior cervical discectomy and arthrodesis for cervical radiculopathy. $\mathrm{J}$ bone and Joint Surg 75-A: 1298-1307, 1993

5. Cizek GR, Boyd LM: Imaging pitfalls of interbody spinal implants. Spine 25: 2633-2636, 2000

6. Cloward RB: The anterior approach for removal of ruptured cervical disks. J Neurosurg 15: 602617, 1958

7. Connolly PJ, Esses SI, Kostuik JP: Anterior cervical fusion: outcome analysis of patients fused with and without anterior cervical fusion. J Spinal Disord 9: 202-206, 1996

8. Coric D, Branch, Jr. CL, Jenkins JD: Revision of anterior cervical pseudarthrosis with anterior allograft fusion and plating. J Neurosurg 86: 969974, 1997

9. Dons K, Gjerris F: Anterior cervical interbody fusion with titanium cages. Rivista di Neuroradiologia 12: 121-123, 1999

10. Elias WJ, Simmons NE, Kaptain GJ, Chadduck JB, Whitehill R: Complications of posterior lumbar interbody fusion when using a titanium threaded cage device. J Neurosurg (Spine 1) 93: 45-52, 2000

11. Gore DR, Sepic SB: Anterior cervical fusion for degenerated or protruded discs. A review of one hundred forty-six patients. Spine 9:667-671, 1984

12. 飛驧一利, 岩崎喜信, 阿部 弘: 頚部脊惟症に対す るチタン製ケージ 1 年以上使用の経過観察。脊椎 脊髄 13: 47-50, 2000

13. 䝷子丸 稔, 小山素麿: 緻密質アパセラムを用いた 頝椎前方固定術の長期成績. 脊椎脊髄 13: 27-32, 2000

14. Ito M, Abumi K, Shono Y, Kotani Y, Minami A, Kaneda K: Complications related to hydroxyapatite vertebral spacer in anterior cervical spine surgery. Spine 27: 428-431, 2002

15. 金粕浩一，本荘 茂，中田理也，林 雅之: 骨折治 療における骨移植・人工骨. 整・災外 44: 345-352, 2001

16. Katsuura A, Hukuda S, Imanaka T, Miyamoto K, Kanemoto M: Anterior cervical plate used in 
degenerative disease can maintain cervical lordosis. J Spinal Disord 9: 470-476, 1996

17. Kim P, Wakai S, Matsuo S, Moriyama T, Kirino T: Bisegmental cervical interbody fusion using hydroxyapatite implants: surgical results and long-term observation in 70 cases. J Neurosurg 88: 21-27, 1998

18. 小山素麿: セラミック使用の歴史. 脊椎脊䯣 13: 3337,2000

19. 久保和親, 中川裕, 黒木実, 亀井裕介, 辻 有紀子, 滝 和郎: Cervical interbody cage fixation. 脊椎脊髄 $13: 39-45,2000$

20. Kuslich SD, Danielson G, Dowdle JD, Sherman J, Fredririckson B, Yuan H, Griffith SL: Four-year follow-up resulys of lumbar spine arthrodesis using the Bagby and Kuslich fusion cage. Spine 25: 2656-2662, 2000

21. Kuslich SD, Ulstrom CL, Griffith SL, Ahern JW, Dowdle JD: The Bagby and Kuslich method of lumbar interbody fusion. History, techniques, and 2-year follow-up results of a United States prospective, multicenter trial. Spine 23: 1267-1279, 1998

22. Leclercq TA: Clinical results and rationale for lumbar interbody fusion with threaded titanium cages. Spinal Surgery 12: 1-9, 1998

23. Matge G: Anterior interbody fusion with the BAK Kage in cervical spondylosis. Acta Neuro Chirochir (Wien) 140: 1-8, 1998

24. 松前信作: 高強度アパタイトの生体親和性の検討. 岐歯学誌 19: 446-459, 1992

25. McAfee PC, Cunningham BW, Lee GA, Orbegoso CM, Haggerty CJ, Fedder IL: revision Strategies for salvaging or improving failed cylindrical cages. Spine 24: 2147-2153, 1999

26. 日本脊椎外科学会編: 脊椎外科用語事典, 東京, 南 江堂, 2000, 163

27. 西山智広, 中島龍夫, 吉村陽子, 中西雄二, 山田 大，近藤和夫，奥山雅彦: $\mathrm{HAP} \cdot \mathrm{TCP}$ 複合体（セラ タイト）の骨伝導能に関する研究－第 1 報: 単独理 入と新鮮自家骨髄混合埋入との比較について一。 形成外科 37: 1273-1280, 1994

28. 織田祥史, 宮武伸一, 德力康彦, 半田肇: セラミッ クス・インプラント（Bioceram）による頝椎前方
固定の経験. Arch Jpn Chir 50: 352-357, 1981

29. 小熊忠教, 畑山明広, 松野誠夫: 神経除圧時の切除 骨と水酸アパタイト・リン酸三カルシウム（セラ タイト）を混合移植した腰椎後側方固定術の骨癒 合の検討．東日本臨整会誌 7: 169-174, 1995

30. 小澤正宏: 高純度 $\beta$-TCPの骨形成能と溶解性に関す る実験的研究. 生体材料 13: 17-25, 1995

31. Rajda BV, Peelen JGJ, de Groot K: Tri-calcium phosphate as a bone substitute. J Bioengin 1997: 93-97, 1977

32. Ray CD: Threaded titanium cages for lumbar interbody fusion cage. Spine 22: 667-680, 1997

33. Riley LH, Robinson RA, Johnson KA, Walker AE: The results of anterior interbody fusion of the cervical spine. J Neurosurg 30: 127-133, 1969

34. Robinson RA, Walker AE, Ferlic DC, Wiecking DK: The result of anterior interbody fusion of the cervical spine. J Bone Joint Surg 44A: 1569-1587, 1962

35. 斉藤明彦, 佐々木 修, 小池哲雄, 田中隆一: 頚椎 前方固定に用いたHydroxyapatite Ceramic Spacer の圧迫・圧潰. Spinal Surgery 15: 191-198, 2001

36. Saito M, Shimizu H, Beppu M, Takagi M: The role of $\beta$-tricalcium phosphate in vascularized periosteum. J Orthop Sci 5: 275-282, 2000

37. Savolainen S, Usenius JP, Hernesniemi J: Iliac crest versus artificial bone grafts in 250 cervical fusions. Acta Neurochir (Wien) 129:54-57, 1994

38. Senter HJ, Kortyna R, Kemp WR: Anterior cervical discectomy with hydroxyapatite fusion. Neurosurgery 25: 39-42, 1989

39. Smith GW, Robinson RA: The treatment of certain cervical-spine disorders by anterior removal of the intervertebral disc and interbody fusion. J Bone Joint Surg 40A: 607-624, 1958

40. 園田武治: 人の脊柱の強度. 京府医大誌 71: 659-702, 1962

41. 高戸 毅, 波利井清紀, 小室裕造, 米原啓之: 水酸 アパタイト・リン酸三カルシウム複合体の骨親和 性抒よび骨誘導能に関する研究. 日形会誌 12: 660667, 1992

42. Thalgott JS, Fritts K, Giuffre JM, Timlin M: Anterior interbody fusion of the cervical spine with coralline hydroxyapatite. Spine 24: 1295-1299, 
1999

43. Wang JC, McDonough PW, Endow KK, Delamarter RB: Increased fusion rates with cervical plating for two-level anterior cervical discectomy and fusion. Spine 25: 41-45, 2000

44. Wang JC, McDonough PW, Endow K, Kanim LE, Delamarter RB: The effect of cervical plating on single-level anterior cervical discectomy and fusion. J Spinal Disord 12: 467-471, 1999

45. Wang JC, Yu WD, Sandhu HS, Betts F, Bhuta S, Delamarter RB: Metal debris from titanium spinal implants. Spine 24: 899-903, 1999
46. Zdeblick TA, Cooke ME, Kunz DN, Wilson DW, McCabe RP: Anterior cervical discectomy and fusion using a porous hydroxyapatite bone graft substitute. Spine 19: 2348-2357, 1994

47. Zdeblick TA, Ducker TA: The use of freeze-dried allograft bone for anterior cervical fusion. Spine 16: 726-729, 1991

\section{Reviewer's comment：小島 精（三重県立総合医療センター 脳神経外科）}

澒椎変性疾患に対する前方除圧，固定術には歴史的にも自家骨，同種骨の移植，緻密体のセラミック，多孔 体のハイドロオキシアパタイト，チ夕ン性のケージ，プレートによる固定等色々あるが，その術式に対する合 併症に対してそれぞれ工夫をして行っている．本論文はこの合併症を少なくするための工夫として，implant にハイドロオキシアパタイトと $\beta$-リン酸三カルシュウムの複合体によるスクリューを考案して用いている. まだ症例の数が少ない点，follow-up期間が短い点，また術後 1 ケ月以内に 4 例において多少のスクリューの逸 脱があった点の解釈およびその解決に問題があるが，本スクリューに大変興味があり，症例を重ねて又発表を して頂きたい.

\section{Reviewer's comment：寶子丸 稔（大津市民病院＼cjkstart脳神経外科）}

本論文は著者らによりデザインされたハイドロキシアパタイト製スクリューを用いた頸椎前方固定術の報告 でありますが，従来のハイドロキシアパタイト製スペーサーに比較して 2 つ新しい点が認められます。スク リュー状の形状が歯み込む構造を提供して接地面積が広いことと，材質が純粋なハイドロキシアパタイトでは なくハイドロキシアパタイトとリン酸三カルシウムの複合体であることです。純粋なハイドロキシアパタイト からなる緻密質アパセラムを用いた前方固定術の大津市民病院の自験例では約 $20 \%$ 症例でスペーサーと骨の 間に骨透梁像が認められています。本スクリューを用いた症例の中には術後 1 年後に骨透梁像を認める症例は ないとのことであり，本スクリューの有用性が示唆されています．しかしながら，スペーサーを 1 椎間あたり 2 個挿入していることもあり，単純レントゲン撮影（特に側面像）では癒合の判定が困難であると思われ，こ の点に関してはC T等などでさらなる検討が必要であると思われます．さらに，本スクリュ一が普及するかど うかは長期成績にかかっているものと思われますので，今後，長期成績に関するレポートが期待されます. 